\title{
PENGARUH KEPEMIMPINAN, KOMPETENSI \\ DAN MOTIVASI TERHADAP KINERJA \\ KARYAWAN PT. TUNAS MANDIRI MIGAS
}

\author{
Nining Purwaningsih \\ Universitas Muhammadiyah Tangerang
}

\begin{tabular}{|c|c|}
\hline INFO ARTKEL & A B S T R AC T \\
\hline $\begin{array}{l}\text { Keyword: } \\
\text { Leadership, competence, } \\
\text { motivation, employee performance }\end{array}$ & $\begin{array}{l}\text { This research aims to know the effect of leadership, competence and } \\
\text { motivation on employees performance. The sample size of this research is } 63 \\
\text { employees out of } 167 \text { employees of PT Tunas Mandiri Migas. The sampling } \\
\text { method used is random sampling. The data gathering technique applied is } \\
\text { questionnaire. The data analysis techniques used are multiple linear regression, } \\
t \text { test and F test. The result of this study shows that leadership, competence and } \\
\text { motivation simultaneously influence the employees performance. The result also } \\
\text { shows that partially leadership and competence influence the employees } \\
\text { performance. Whereas motivation partially does not influence the employees } \\
\text { performance. }\end{array}$ \\
\hline
\end{tabular}

\section{N T I SAR I}

Penelitian ini bertujuan untuk mengetahui pengaruh kepemimpinan, kompetensi dan motivasi terhadap kinerja karyawan. Ukuran sampel penelitian ini adalah 63 karyawan dari 167 karyawan PT Tunas Mandiri Migas. Metode pengambilan sampel yang digunakan adalah random sampling. Teknik pengumpulan data yang digunakan adalah kuesioner. Teknik analisis data yang digunakan adalah regresi linier berganda, uji t dan uji F. Hasil penelitian ini menunjukkan bahwa kepemimpinan, kompetensi dan motivasi secara simultan mempengaruhi kinerja karyawan. Hasil penelitian juga menunjukkan secara parsial kepemimpinan dan kompetensi mempengaruhi kinerja karyawan. Sedangkan motivasi secara parsial tidak mempengaruhi kinerja karyawan. 


\section{PENDAHULUAN}

\section{Latar Belakang Masalah}

Hubungan antara individu dan kelompok dalam organisasi menciptakan harapan-harapan individu. sebagian orang harus memainkan peranan sebagai pemimpin,sementara yang lain peranannya sebagai pengikut.untuk mengatur ataupun mengarahkan interaksi tersebut agar dapat mencapai tujuan, maka diperlukan leadreship atau kepemimpinan.

Sumber Daya Manusia yang pontensial apabila didayagunakan secara efektif dan efisien akan bermanfaat untuk menunjang gerak lajunya perusahaan (Koesmono, 2006). Terbukti perusahaan yang bertahan adalah perusahaan yang memiliki sumber daya manusia yang dapat diandalkan dan memiliki kinerja yang baik.

Seperti yang dikatakan Moeheriono (2012) salah satu fakor yang paling penting dan mampu menentukan keberhasilan atau kegagalan organisasi adalah faktor sumber daya manusia. Pada berbagai bidang khususnya kehidupan berorganisasi, faktor manusia merupakan masalah utama disetiap kegiatan yang ada didalamnya. Organisasi merupakan kesatuan sosial yang dikoordinasikan secara sadar dengan sebuah batasan yang reaktif dapat diidentifikasikan, bekerja secara terus menerus untuk mencapai tujuan (Robbins, 2006).

Selain kepemimpinan, masalah lain yang sering timbul adalah masalah bisnis yang berkaitan dengan kinerja, yaitu mengelola sumber daya manusia untuk menciptakan kemampuan (kompetensi) yang harus dimiliki oleh seorang karyawan guna melaksanakan pekerjaannya, sehingga dengan adanya kompetensi yang telah dimiliki akan dapat membantu para karyawan dalam menyelesaikan pekerjaannya yang sesuai dengan target yang akan dicapai.

Kompetensi dapat memperdalam dan memperluas kemampuan kerja. Semakin sering seseorang melakukan pekerjaan yang sama, semakin terampil dan cepat pula dia menyelesaikan pekerjaan tersebut..

Motivasi merupakan proses pemberian motif bekerja kepada para pegawai sehingga mereka mau bekerja demi tercapainya tujuan organisasi secara efektif dan efesien. Dengan terpenuhinya semua kebutuhan atau keinginan dan harapan maka pegawai akan mendapatkan kepuasan, dan pegawai yang tingkat kepuasannya tinggi maka secara otomatis kinerjanya akan meningkat.

Dalam rangka meningkatkan kinerja pegawai, maka banyak faktor yang perlu dipertimbangkan, di antaranya adalah kompetensi, motivasi dan kompensasi. Dalam kompetensi tidak hanya terdapat keterampilan, pengetahuan, dan sikap tetapi bagaimana cara menerapkannya agar sesuai dengan standar kinerja.

PT. Tunas Mandiri Migas merupakan perusahaan di bidang Trading Migas, berdasarkan wawancara dengan manager HRD pada tanggal 12 Januari 2017, ia menyatakan bahwa selama tahun 2017 telah terjadi penurunan penjualan, walaupun pihak HRD telah mengadakan traning penjualan kepada karyawan secara berkelanjutan. la menduga hal ini disebabkan oleh pimpinan yang kurang memahami keinginan dan kebutuhan karyawan, kurangnya kompetensi karyawan dan rendahnya motivasi karyawan.

\section{Rumusan Masalah}

Berdasarkan latar belakang masalah di atas, maka penelitian ini akan dirumuskan dalam beberapa pertanyaan sebagai berikut:

I. Apakah Kepemimpinan berpengaruh positif dan signifikan terhadap Kinerja Karyawan?

2. Apakah Kompetensi berpengaruh positif dan signifikan terhadap Kinerja Karyawan?

3. Apakah Motivasi berpengaruh positif dan signifikan terhadap Kinerja Karyawan?

4. Apakah Kepemimpinan, Kompetensi dan Motivasi secara bersama-sama (simultan) berpengaruh signifikan terhadap kinerja karyawan?

\section{TINJAUAN PUSTAKA}

\section{Kepemimpinan}

Kepemimpinan dapat diartikan sebagai proses mempengaruhi dan mengarahkan para pegawai dalam melakukan pekerjaan yang telah ditugaskan kepada mereka. Sebagaimana didefinisikan oleh Stoner, Freeman, dan Gilbert (1995), kepemimpinan adalah the process of directing and influencing the task related activities of group members. Kepemimpinan adalah proses dalam mengarahkan dan mempengaruhi para anggota dalam hal berbagai aktivitas yang harus dilakukan. Lebih jauh lagi, Griffin (2000) 
membagi pengertian kepemimpinan menjadi dua konsep, yaitu sebagai proses, dan sebagai atribut. Kepemimpinan merupakan serangkaian usaha yang dilakukan oleh pimpinan untuk mempengaruhi kinerja para bawahannya, dalam upaya untuk meningkatkan kualitas kinerja karyawan dengan berpengaruhnya seorang pemimpin dan adanya hubungan yang baik antara pemimpin dan bawahan maka akan mendukung sepenuhnya terhadap kebijakan yang dilakukan pemimpin.

\section{Kompetensi}

Menurut Wibowo (2012), pengertian kompetensi merupakan kemampuan melaksanakan pekerjaan atau tugas yang didasari ketrampilan maupun pengetahuan dan didukung oleh sikap kerja yang ditetapkan oleh pekerjaan.Kompetensi menunjukan pengetahuan, ketrampilan dan sikap tertentu dari suatu profesi dalam ciri keahlian tertentu, yang menjadi ciri dari seorang profesional.

Kompetensi secara harfiah berasal dari kata competence, yang berarti kemampuan, wewenangan kecakapan. Dari segi etimologi, kompetensi berarti segi keunggulan, keahlian dari perilaku seseorang pegawai atau pemimpin yang mana punya suatu pengetahuan, perilaku dan ketrampilan yang baik. Karakteristik dari kompetensi yaitu sesuatu yang menjadi bagian dari karakter pribadi dan menjadi bagian dari prilaku seseorang dalam melaksanakan suatu tugas pekerjaan (Mangkunegara, 2007)

\section{Kompetensi merupakan suatu kemampuan untuk melaksanakan atau melakukan suatu pekerjaan atau tugas yang dilandasi atas ketrampilan dan pengetahuan dan didukung oleh sikap kerja yang dituntut oleh pekerjaan tersebut.}

\section{Motivasi}

\begin{abstract}
Motivasi merupakan faktor penggerak maupun dorongan yangdapat memicu timbulnya rasa semangat dan juga mampu merubah tingkah laku manusia atau individu untuk menuju pada hal yang lebihbaik untuk dirinya sendiri. Sardiman (1986) menjelaskan motivasi belajar merupakan faktor psikis yang bersifat non intelektual.
\end{abstract}

\section{Kinerja Karyawan}

Kinerja adalah hasil seseorang secara keseluruhan selama periode tertentu didalam melaksanakan tugas, seperti standar hasil kerja, target atau sasaran kriteria yang telah ditentukan terlebih dahulu dan telah disepakati bersama (Veithzal, 2005:97).

\section{Kerangka Pemikiran}

Di dalam suatu perusahaan, kinerja merupakan hal yang terpenting. Hal tersebut perlu didukung dengan kepemimpinan, kompetensi dan motivasi. Kepemimpinan yang baik dapat mempengaruhi orang lain untuk bekerja sama dengan baik. Kompetensi dapat memperdalam dan memperluas kemampuan kerja sedangkan Motivasi merupakan dorongan atau semangat yang membuat seseorang mempunyai tujuan dan ukuran standar yang akan dicapai.

Dari penjelasan di atas dapat digambarkan sebuah model kerangka pemikiran sebagai berikut:

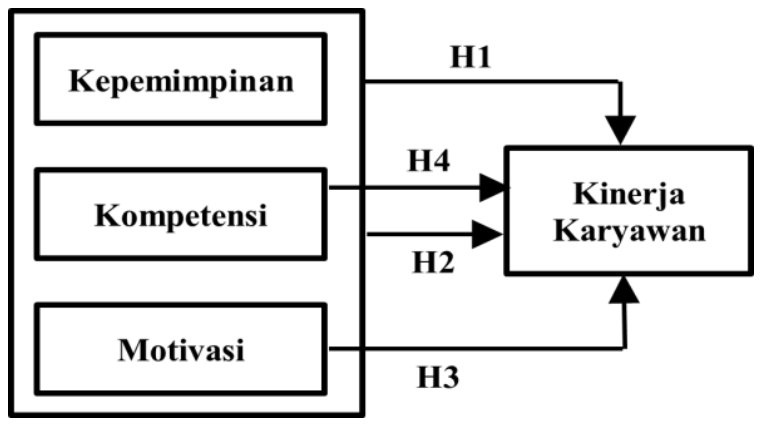

Gambar I Kerangka Konseptual

\section{Hipotesis}

Berdasarkan latar belakang, rumusan masalah serta kerangka konseptual di atas maka dapatlah diberikan hipotesis dalam penelitian ini yaitu:

HI: Terdapat pengaruh positif dan signifikan kepemimpinan terhadap kinerja karyawan.

H2: Terdapat pengaruh positif dan signifikan kompetensi terhadap kinerja karyawan.

H3: Terdapat pengaruh positif dan signifikan motivasi terhadap kinerja karyawan

H4: Terdapat pengaruh positif dan signifikan kepemimpinan, kompetensi dan motivasi bersama-sama (simultan) mempengaruhi kinerja karyawan.

\section{METODE PENELITIAN}

\section{Variabel Penelitian}

Variabel penelitian adalah hal-hal yang dapat membedakan atau membawa variasi pada nilai (Sekaran, 20I4). Penelitian ini menggunakan 
dua variabel yaitu variabel independen dan variabel dependen.

\section{Variabel dependen (variabel terikat)}

Variabel dependen merupakan variabel yang menjadi pusat perhatian peneliti. Hakekat sebuah masalah, mudah terlihat dengan mengenali berbagai variabel dependen yang digunakan dalam sebuah model (Ferdinand, 2006). Dalam penelitian ini yang menjadi variabel terikat adalah kinerja karyawan $(\mathrm{Y})$.

\section{Variabel independen (variabel bebas)}

Variabel independen adalah variabel yang mempengaruhi variabel dependen, baik yang pengaruhnya positif maupun yang pengaruhnya negatif (Ferdinand, 2006). Dalam penelitian ini yang menjadi variabel-variabel bebas adalah kepemimpinan $\left(X_{1}\right)$, kompetensi $\left(X_{2}\right)$ dan motivasi $\left(\mathrm{X}_{3}\right)$.

\section{Definisi Operasional}

Definisi operasional yang digunakan dalam penelitian ini kemudian diuraikan menjadi indikator empiris seperti yang dijelaskan pada tabel berikut:

Tabel 3.I Definisi Operasional Variabel

\begin{tabular}{|c|c|c|}
\hline Variabel & Definisi Operasional & Indikator \\
\hline $\begin{array}{l}\text { Kepemimpinn } \\
(\mathrm{XI})\end{array}$ & $\begin{array}{lr}\text { Kepemimpinan } & \text { adalah } \\
\text { serangkaian usaha yang } & \text { oleh } \\
\text { dilakukan } & \text { untuk } \\
\text { pimpinan } & \text { mempengaruhi kinerja } \\
\text { para bawahannya, } & \text { dalam upaya untuk } \\
\text { meningkatkan kualitas } \\
\text { kinerja pegawai }\end{array}$ & $\begin{array}{ll}\text { a. } & \text { Pengaruh. } \\
\text { b. } & \text {.Hubungan } \\
\text { kepemimp } \\
\text { inan } \\
\text { dengan } \\
\text { anggota }\end{array}$ \\
\hline $\begin{array}{l}\text { Kompetensi } \\
(\mathrm{X} 2)\end{array}$ & $\begin{array}{l}\text { Kompetensi adalah hal- } \\
\text { hal yang mampu } \\
\text { dilakukan seseorang } \\
\text { dalam meningkatkan } \\
\text { kinerjanya. } \\
\text { Indikatornya adalah: }\end{array}$ & $\begin{array}{l}\text { a. Kemampuan } \\
\text { b. Pengetahuan }\end{array}$ \\
\hline Motivasi (X3) & $\begin{array}{lr}\text { Motivasi } & \text { adalah } \\
\text { keinginan kerja untuk } \\
\text { mencapai } & \text { suatu tujuan, } \\
\text { dimana } & \text { keinginan } \\
\text { tersebut } & \text { dapat } \\
\text { merangsang } & \text { dan } \\
\text { membuat seseorang } \\
\text { untuk mau melakukan } \\
\text { pekerjaan atau apa } \\
\text { yang mengakibatkan } \\
\text { timbulnya r motivasi } \\
\text { kerja }\end{array}$ & $\begin{array}{l}\text { a.Kebutuhan } \\
\text { untuk } \\
\text { mencapai } \\
\text { prestasi. } \\
\text { b.Penghargaan. }\end{array}$ \\
\hline $\begin{array}{l}\text { Kinerja } \\
\text { karyawan }(\mathrm{Y})\end{array}$ & $\begin{array}{l}\text { Kinerja adalah hasil } \\
\text { pekerjaan yang dicapai }\end{array}$ & $\begin{array}{ll}\text { a. } & \text { Kuali } \\
& \text { tas }\end{array}$ \\
\hline
\end{tabular}

\begin{tabular}{|l|l|ll|}
\hline & $\begin{array}{l}\text { seseorang berdasarkan } \\
\text { persyaratan- } \\
\text { persyaratan pekerjaan. }\end{array}$ & b. & $\begin{array}{l}\text { Kerja } \\
\text { titas }\end{array}$ \\
& c. & $\begin{array}{l}\text { Disip } \\
\text { lin }\end{array}$ \\
\hline
\end{tabular}

Sumber: Diolah untuk penelitian ini, 2017

Populasi adalah wilayahgeneralisasi yang atas obyek /subyek yang mempunyai kualitas dan karakteristik tertentu yang ditetapkan oleh peneliti untuk dipelajari dan kemudian akan ditarik suatu kesimpulan (Sugiyono, 2008). Populasi penelitian ini adalah seluruh karyawan yang bekerja di PT. Tunas Mandiri Migas Jakarta.

Sampel adalah bagian dari jumlah karakteristik yang dimiliki oleh populasi tersebut (Sugiyono, 2008:80). Sampel dalam penelitian ini adalah sebagian dari karyawan yang bekerja di PT. Tunas Mandiri Migas Jakarta. Untuk mendukung penelitian ini, maka peneliti akan menyebarkan angket sebanyak 63 angket dari 167 karyawan yang bekerja di Kantor PT. Tunas Mandiri Migas Jakarta. Perhitungan jumlah sampel dilakukan dengan rumus Slovin, yaitu:

$$
\begin{aligned}
& \mathrm{n}=\mathrm{N} /\left(\mathrm{I}+\mathrm{Ne}^{2}\right) \\
& \mathrm{n}=167 /(2.67)=62,55 \text { dibulatkan } 63
\end{aligned}
$$

\section{Keterangan}

$\mathrm{n}=$ ukuran sampel

$\mathrm{N}=$ jumlah populasi

$\mathrm{e}=$ nilai kritis yang digunakan $(0, \mathrm{I})$

\section{Analisis Regresi Linear Berganda}

Secara umum analisis ini digunakan untuk meneliti pengaruh dari beberapa variabel independen (variabel $X$ ) terhadap variabel dependen (variabel Y) (Ghozali, 2006). Pada regresi berganda variabel independen (variabel $X)$ yang diperhitungkan pengaruhnya terhadap variabel dependen (variabel $Y$ ), jumlahnya lebih dari satu. Dalam penelitian ini, variabel independen adalah Kepemimpinan $\left(X_{1}\right)$, Kompetensi $\left(X_{2}\right)$ dan Motivasi $\left(X_{3}\right)$ sedangkan variabel dependen adalah Kinerja Karyawan $(Y)$ sehingga persamaan regresi bergandanya adalah:

$Y=a+b_{1} X_{1}+b_{2} X_{2}+b_{3} X_{3}+e$

\section{Dimana:}

Y : Kinerja Pegawai

a : Konstanta

$b_{1}, b_{2}, b_{3}$ : Koefisien masing-masing faktor

$X_{1}$ : Kepemimpinan

$\mathrm{X}_{2}$ : Kompetensi

$X_{3}$ : Motivasi 


\section{Pengujian Hipotesis}

Untuk mengetahui pengaruh masingmasing variabel independen pada variabel terikat perlu dilakukan pengujian signifikansi dari masing-masing koefisien regresi yaitu dengan menggunakan Uji t dan uji $F$.

Uji $t$ didgunakan untuk mengetahui pengaruh variabel independen secara parsial terhadap variabel dependen, apakah pengaruhnya signifikan atau tidak (Priyatno, 2009).

Uji $F$ pada dasarnya menunjukan apakah semua variabel independen atau bebas yang dimasukan dalam model mempunyai pengaruh secara bersama-sama terhadap variabel dependen atau terikat (Priyatno, 2009).

\section{HASIL PENELITIAN}

\section{Analisis Regresi Berganda}

Berikut hasil perhitungan regresi linier berganda antara variabel kepemimpinan $\left(X_{1}\right)$, kompetensi $\left(\mathrm{X}_{2}\right)$ dan motivasi $\left(\mathrm{X}_{3}\right)$ terhadap Kinerja karyawan (Y). Melalui proses perhitungan SPSS 22 dapat diperoleh hasil sebagai berikut:

Tabel 4.I Hasil Pengolahan Data Regresi Linier Berganda

\begin{tabular}{|ll|r|r|}
\hline \multirow{2}{*}{ Model } & \multicolumn{2}{|c|}{$\begin{array}{c}\text { Unstandardized } \\
\text { Coefficients }\end{array}$} \\
\cline { 2 - 3 } 1 & \multicolumn{1}{|c|}{ B } & Std. Error \\
\hline 1 Constant) & 6.447 & 3.974 \\
& Kepemimpinan & .457 & .123 \\
\cline { 2 - 3 } Kompetensi & .560 & .163 \\
\multicolumn{2}{|c|}{ Motivasi } & -.133 & .246 \\
\hline
\end{tabular}

a. Dependent Variable: Kinerja Karyawan

Sumber: Data primer diolah, 2017

Sehingga dari persamaan rumus regresi linier berganda dapat diperoleh hasil sebagai berikut:

$Y=6,447+0,457 X_{1}+0,560 X_{2}-0,133 X_{3}$

Hasil persamaan regresi berganda tersebut diatas memberikan pengertian bahwa:

a. Nilai konstanta 6,447 mempunyai arti bahwa apabila variabel-variabel independen yaitu kepemimpinan, kompetensi dan motivasi itu konstan atau tidak berubah maka perubahan kinerja karyawan positif.

b. b। (nilai koefisien regresi $X_{1}$ ) 0,457 mempunyai arti bahwa jika kepemimpinan lebih ditingkatkan sedangkan variabel lain adalah tetap (konstan) maka kinerja karyawan juga akan meningkat.

c. $b_{2}$ (nilai koefisien regresi $X_{2}$ ) 0,560 mempunyai arti bahwa jika kompetensi lebih ditingkatkan sedangkan variabel lain adalah tetap (konstan) maka kinerja karyawan juga akan meningkat.

d. b3 (nilai koefisien regresi $\left(X_{3}\right)-0,133$ mempunyai arti bahwa jika motivasi diturunkan sedangkan variabel lain adalah tetap (konstan) maka kinerja karyawan akan meningkat.

\section{Analisis Koefisien Determinasi}

Koefisien determinasi digunakan untuk mengetahui seberapa besar variabilitas variabel independen dalam menjelaskan variabel dependen yang ditunjukkan oleh nilai Adjusted $R$ square $\left(R^{2}\right)$ yaitu sebesar 0,445 artinya variabilitas variabel kepemimpinan, kompetensi dan motivasi hanya mampu menjelaskan Kinerja karyawan $44,5 \%$, sedangkan sisanya sebesar $55,5 \%$ dipengaruhi oleh variabilitas variabel lain yang tidak diteliti dalam penelitian ini. Hasil keluaran SPSS 22 dari koefisien determinasi dapat dilihat pada tabel dibawah ini.

Tabel 4.2 Koefisien Determinasi

\begin{tabular}{|c|c|c|c|c|}
\hline \multicolumn{5}{|c|}{ Model Summary } \\
\hline Model & $\mathrm{R}$ & R Square & $\begin{array}{l}\text { Adjusted } \\
\text { R Square }\end{array}$ & $\begin{array}{l}\text { Std. Error of } \\
\text { the Estimate }\end{array}$ \\
\hline 1 & $.687^{9}$ & .472 & .445 & 2.51385 \\
\hline
\end{tabular}

\section{Pengujian Hipotesis}

Pengujian hipotesis dilakukan untuk mengetahui apakah persamaan regresi yang diperoleh dapat dipertanggung jawabkan atau tidak. Bila hasil analisis nanti menunjukkan bahwa persamaan regresi yang bersangkutan adalah signifikan atau dapat dipertanggung jawabkan, maka persamaan regresi tersebut dapat digunakan untuk meramalkan variabel $Y$ dan sekaligus untuk membuktikan hipotesis yang diajukan.

\section{Pengujian Hipotesis Secara Parsial (Uji t)}

Uji $t$ digunakan untuk mengetahui pengaruh kepemimpinan $\left(X_{1}\right)$, kompetensi $\left(X_{2}\right)$ dan motivas $\left(X_{3}\right)$ secara parsial terhadap kinerja karyawan $(\mathrm{Y})$. 
Tabel 4.3 Uji Hipotesis Secara Parsial (Uji t)

Coefficients $^{\mathrm{a}}$

\begin{tabular}{|c|c|c|c|c|c|}
\hline \multirow[b]{2}{*}{ Model } & \multicolumn{2}{|c|}{$\begin{array}{c}\text { Unstandardized } \\
\text { Coefficients }\end{array}$} & \multirow{2}{*}{$\begin{array}{c}\text { Standardized } \\
\text { Coefficients } \\
\text { Beta } \\
\end{array}$} & \multirow[b]{2}{*}{$t$} & \multirow[b]{2}{*}{ Sig. } \\
\hline & $B$ & Std. Error & & & \\
\hline 1 (Constant) & 6.447 & 3.974 & & 1.622 & .110 \\
\hline Kepemimpinan & .457 & .123 & .440 & 3.713 & .000 \\
\hline Kompetensi & .560 & .163 & .414 & 3.430 & .001 \\
\hline Motivasi & -.133 & 246 & -.071 & -.542 & .590 \\
\hline
\end{tabular}

a. Dependent Variable: Kinerja Karyawan

Sumber: Data primer diolah, 2017

Hasil pengujian hipotesis menunjukkan bahwa nilai t hitung untuk kepemimpinan adalah $3,7 / 3$ dengan signifikansinya sebesar 0,000 ; sedangkan pada taraf signifikansi sebesar 0,025 dengan degree of freedom (df) sebesar $=59$ diperoleh nilai $\mathrm{t}$ tabel sebesar $2,00 \mathrm{I}$ sehingga nilai $\mathrm{t}$ hitung $=3,7 \mid 3>$ nilai $t$ tabel $=2,00 \mathrm{I}$. Dengan demikian menunjukkan bahwa kepemimpinan $\left(X_{1}\right)$ berpengaruh positif signifikan terhadap kinerja karyawan $(\mathrm{Y})$.

Hasil pengujian hipotesis menunjukkan bahwa nilai $t$ hitung untuk kompetensi adalah 3,430 dengan signifikansinya sebesar $0,00 \mathrm{I}$; sedangkan pada taraf signifikansi sebesar 0,025 dengan degree of freedom $(\mathrm{df})$ sebesar $=59$ diperoleh nilai $t$ tabel sebesar $2,00 \mathrm{I}$ sehingga nilai $\mathrm{t}$ hitung $=3,430>$ nilai $\mathrm{t}$ tabel $=2,00 \mathrm{I}$. Dengan demikian menunjukkan bahwa kompetensi $\left(\mathrm{X}_{2}\right)$ berpengaruh positif signifikan terhadap kinerja karyawan $(\mathrm{Y})$.

Hasil pengujian hipotesis menunjukkan bahwa nilai $t$ hitung untuk motivasi adalah $-0,133$ dengan signifikansinya sebesar 0,590 ; sedangkan pada taraf signifikansi sebesar 0,025 dengan degree of freedom $(\mathrm{df})$ sebesar $=59$ diperoleh nilai $t$ tabel sebesar $2,00 \mathrm{I}$ sehingga nilai $\mathrm{t}$ hitung $=0,133<$ nilai $t$ tabel $=2,00 \mathrm{I}$. Dengan demikian menunjukkan bahwa motivasi $\left(X_{3}\right)$ berpengaruh negatif dan tidak signifikan terhadap kinerja karyawan $(\mathrm{Y})$.

Dengan demikian dapat disimpulkan bahwa kepemimpinan dan kompetensi secara parsial berpengaruh terhadap kinerja karyawan, sedangkan motivasi secara parsial tidak berpengaruh terhadap kinerja karyawan.

\section{Pengujian Hipotesis Secara Simultan (uji F)}

Uji $F$ digunakan untuk mengetahui pengaruh kepemimpinan $\left(X_{1}\right)$, kompetensi $\left(X_{2}\right)$ dan motivasi $\left(\mathrm{X}_{3}\right)$ secara bersama-sama (simultan) terhadap kinerja karyawan (Y).
Tabel 4.4 Uji Hipotesis Secara Simultan (Uji F)

\begin{tabular}{|c|c|c|c|c|c|}
\hline \multicolumn{6}{|c|}{ ANOVAa } \\
\hline Model & $\begin{array}{l}\text { Sum of } \\
\text { Squares }\end{array}$ & df & $\begin{array}{c}\text { Mean } \\
\text { Square }\end{array}$ & $\mathrm{F}$ & Sig. \\
\hline 1 Regression & 332.709 & 3 & 110.903 & 17.550 & $.000^{b}$ \\
\hline Residual & 372.846 & 59 & 6.319 & & \\
\hline Total & 705.556 & 62 & & & \\
\hline
\end{tabular}

a. Dependent Variable: Kinerja Karyawan

b. Predictors: (Constant), Motivasi, Kepemimpinan, Kompetensi

Sumber: Data primer diolah, 2017

Hasil perhitungan yang telah dilakukan diperoleh nilai $F$ hitung adalah sebesar 17,550 sedangkan degree of freedom ( $\mathrm{df}$ ) pada angka 3 dan 59 dalam tabel $F$ diperoleh nilai sebesar 2,76I sehingga nilai $F$ hitung sebesar $17,550>$ nilai $F$ tabel $=2,76 \mathrm{I}$. Hal ini menunjukkan bahwa terdapat pengaruh signifikan secara bersamasama antara kepemimpinan $\left(X_{1}\right)$, kompetensi $\left(X_{2}\right)$ dan motivasi $\left(X_{3}\right)$ secara bersama-sama (simultan) terhadap kinerja karyawan (Y).

\section{PEMBAHASAN}

I. Pengaruh positif dan signifikan kepemimpinan terhadap kinerja karyawan

Hasil penelitian menunjukkan bahwa terdapat pengaruh positif dan signifikan kepemimpinan terhadap kinerja karyawan. Hasil pengujian hipotesis menunjukkan bahwa nilai $t$ hitung untuk kepemimpinan adalah 3,7 3 dengan signifikansinya sebesar 0,000 ; sedangkan pada taraf signifikansi sebesar 0,025 dengan $\mathrm{df}$ sebesar $=59$ diperoleh nilai $\mathrm{t}$ tabel sebesar $2,00 \mathrm{I}$ sehingga nilai $\mathrm{t}$ hitung $=3,7 \mathrm{I} 3>$ nilai $\mathrm{t}$ tabel $=2,00 \mathrm{I}$. Dengan demikian menunjukkan bahwa terdapat pengaruh signifikan antara kepemimpinan $\left(X_{1}\right)$ terhadap kinerja karyawan (Y).

Hipotesis pertama $(\mathrm{HI})$ menyebutkan bahwa terdapat pengaruh positif dan signifikan kepemimpinan terhadap kinerja karyawan, berhasil didukung oleh data atau dengan kata lain hipotesis diterima. Semakin tinggi tingkat kepemimpinan yang dimiliki pimpinan, maka kinerja karyawan akan semakin baik.

Kepemimpinan merupakan hal penting, maka sebaiknya perusahaan meningkatkan kepemimpinan, dengan memperhatikan pengaruh pimpinan dalam berbuat sesuatu yang membuat karyawan senang bekerja, menunjukkan hal-hal yang dapat menarik minat kerja karyawan, selalu memperhatikan konflik yang terjadi diantara karyawan, selalu mendorong karyawan untuk bekerja maksimal, 
selalu memberitahukan dengan jelas apa yang harus dikerjakan, dan bagaimana mengerjakannya, selalu melakukan hubungan baik dengan karyawan, memberikan kesempatan kepada para karyawan untuk mendiskusikan masalah-masalah dengan pimpinan, dan melibatkan partisipasi karyawan dalam setiap kegiatan, maka dengan demikian hal-hal tersebut akan semakin meningkatkan kinerja para karyawan.

\section{Pengaruh positif dan signifikan Kompetensi terhadap Kinerja Karyawan}

Hasil penelitian menunjukkan bahwa terdapat pengaruh positif dan signifikan kompetensi terhadap kinerja karyawan. Hasil pengujian hipotesis menunjukkan bahwa nilai $t$ hitung untuk kompetensi adalah 3,430 dengan signifikansinya sebesar $0,00 \mathrm{I}$; sedangkan pada taraf signifikansi sebesar 0,025 dengan df sebesar $=59$ diperoleh nilai $\mathrm{t}$ tabel sebesar $2,00 \mathrm{I}$ sehingga nilai $\mathrm{t}$ hitung $=3,430>$ nilai $\mathrm{t}$ tabel $=2,00 \mathrm{I}$. Dengan demikian menunjukkan bahwa terdapat pengaruh signifikan antara kompetensi $\left(\mathrm{X}_{2}\right)$ terhadap kinerja karyawan $(\mathrm{Y})$.

Hipotesis kedua $(\mathrm{H} 2)$ menyebutkan bahwa terdapat pengaruh positif dan signifikan kompetensi terhadap kinerja karyawan, berhasil didukung oleh data atau dengan kata lain hipotesis diterima. Semakin tinggi tingkat kompetensi yang dimiliki karyawan, maka kinerja karyawan akan semakin baik.

Kompetensi menjadi penting, maka untuk meningkatkan kinerja karyawan, sebaiknya perusahaan lebih memperhatikan usaha untuk meningkatkan karier yang dilakukan para karyawan untuk mencapai prestasi, agar karyawan bekerja keras untuk mencapai hasil yang maksimal untuk naik ke jenjang pekerjaan lebih tinggi dan berusaha untuk menjadi yang terbaik diantara rekan-rekan kerja. Dengan demikian hal-hal tersebut dapat meningkatkan kinerja para karyawan menjadi lebih baik.

\section{Pengaruh negatif dan tidak signifikan Motivasi terhadap Kinerja Karyawan}

Hasil penelitian menunjukkan bahwa terdapat pengaruh negatif dan tidak signifikan motivasi terhadap kinerja karyawan. Hasil pengujian hipotesis menunjukkan bahwa nilai $t$ hitung untuk motivasi adalah -0,542 dengan signifikansinya sebesar 0,590 ; sedangkan padataraf signifikansi sebesar 0,025 dengan df sebesar $=59$ diperoleh nilai $\mathrm{t}$ tabel sebesar 2,001 sehingga nilai $t$ hitung $=0,542<$ nilai $t$ tabel $=2,00 \mathrm{I}$. Dengan demikian menunjukkan bahwa terdapat pengaruh negatif tidak signifikan antara motivasi $\left(\mathrm{X}_{3}\right)$ terhadap kinerja karyawan (Y).

Hipotesis ketiga $(\mathrm{H} 3)$ menyebutkan bahwa terdapat pengaruh positif dan signifikan motivasi terhadap terhadap kinerja karyawan, tidak berhasil didukung oleh data atau dengan kata lain hipotesis ditolak. Artinya motivasi tidak berpengaruh terhadap kinerja karyawan. $\mathrm{Hal}$ ini mungkin disebabkan oleh motivasi yang dimiliki oleh para karyawan sudah sesuai dengan kebutuhan mereka untuk meningkatkan kinerja mereka.

4. Pengaruh kepemimpinan, kompetensi dan motivasi secara bersama-sama (simultan) terhadap kinerja Karyawan

Berdasarkan hasil dari analisis pengaruh kepemimpinan, kompetensi dan motivasi terhadap kinerja pegawai melalui uji $\mathrm{F}$ dapat diketahui bahwa variabel-variabel bebas (kepemimpinan, kompetensi dan motivasi) mempunyai pengaruh secara bersama-sama terhadap variabel terikatnya (kinerja karyawan). $\mathrm{Hal}$ ini dapat ditunjukkan melalui hasil uji $\mathrm{F}$ dengan nilai $F$ hitung sebesar 17,550 dengan $P$ value sebesar 0,000 . Nilai $F$ hitung yang diperoleh menunjukkan nilai yang lebih besar dari $\mathrm{F}$ tabel $(\mathrm{F}$ hitung $>\mathrm{F}$ tabel; $17,550>2,76 \mathrm{I})$ dan nilai signifikan yang lebih kecil dari $5 \%$ $(0,000<0,05)$, dapat disimpulkan bahwa variabel-variabel bebas dalam penelitian ini (kepemimpinan, kompetensi dan motivasi) secara bersama-sama mempengaruhi variabel terikatnya (kinerja karyawan).

Hipotesis empat (H4) menyebutkan bahwa terdapat pengaruh positif dan signifikan kepemimpinan, kompetensi dan motivasi secara bersama-sama (simultan) terhadap kinerja karyawan berhasil didukung oleh data atau dengan kata lain hipotesis diterima. Kinerja karyawan akan semakin meningkat bila dikaitkan dengan semakin efektifnya kepemimpinan, kompetensi yang semakin tinggi dan motivasi yang semakin kuat dari seorang karyawan.

\section{PENUTUP}

\section{Kesimpulan}

Berdasarkan penelitian yang telah dilakukan maka dapat diperoleh kesimpulan sebagai berikut: 
I. Terdapat pengaruh positif dan signifikan antara kepemimpinan, kompetensi dan motivasi secara bersama-sama (simultan) terhadap kinerja karyawan.

2. Hasil uji signifikansi terhadap nilai koefisien regresi secara parsial yang berpengaruh signifikan terhadap kinerja karyawan adalah variabel kepemimpinan dan variabel kompetensi sedangkan variabel motivasi yang tidak berpengaruh terhadap kinerja karyawan adalah variabel motivasi.

3. Berdasarkan hasil uji R2 variabel bebas (kepemimpinan, kompetensi dan motivasi) memberikan kontribusi perubahan dalam variabel terikat (kinerja karyawan) sebesar $44,5 \%$.

\section{Saran}

Berdasarkan hasil penelitian maka dapat diberikan saran-saran sebagai berikut:

I. Bagi perusahaan, hendaknya memperhatikan faktor kepemimpinan dan kompetensi karena faktor tersebut terbukti memiliki pengaruh terhadap kinerja karyawan.

2. Penelitian ini masih terbatas pada kepemimpinan, kompentesi dan motivasi, untuk peneliti selanjutnya dapat dilakukan penambahan variabel penelitian yang juga berpengaruh terhadap kinerja karyawan misalnya kompensasi, kedisiplinan dan kemampuan.

3. Penelitian akan lebih baik apabila tidak hanya menggunakan kuesioner saja tetapi dilengkapi dengan teknik wawancara atau metode lain agar bias mendapatkan data yang lebih valid dan sesuai dengan kenyataan yang sebenarnya.

\section{DAFTAR PUSTAKA}

Bernadin, H. John., and E.A. Russell. 1993, Human Resource Management, International Edition. Singapore: McGraw Hill, Inc.

Ferdinand, Augusty. 20II, Metode Penelitian Manajemen Pedoman Penelitian untuk Penulisan Skripsi, Tesis, dan Disertasi Ilmu Manajemen. Edisi 3. AGF Books. Fakultas Ekonomika dan Bisnis Universitas Diponegoro. Semarang.
Ghozali, Imam. 2006, Aplikasi Analisis Multivariate dengan Program SPSS. Semarang: Badan Penerbit UNDIP.

Griffin, Ricky. 2000, Management, Edisi 2. Jakarta: Erlangga.

Koesmono, 2006, Jurnal Manajemen Bisnis, Volume 5, No.l. Fakultas Ekonomi Universitas Surabaya. Surabaya.

Mangkunegara, A.A. Anwar Prabu. 2007, Manajemen Sumber Daya Manusia Perusahaan. Bandung: PT. Remaja Rosdakarya.

Moeheriono. 2012, Pengukuran Kinerja Berbasis Kompetensi. Jakarta: Raja Grafindo Persada..

Priyatno, Duwi. 2009, SPSS untuk Analisis Korelasi, Regresi, dan Multivariate. Yogyakarta: Gava Media.

Rivai, Veithzal, 2005, Manajemen Sumber Daya Manusia untuk Perusahaan, dari Teori ke Praktik, Jakarta: PT. Raja Grafindo Persada.

Robbins, Stephen. P. 2006. Perilaku organisasi. Edisi Bahasa Indonesia. PT Indeks Kelompok Gramedia. Jakarta.

Ruky, Achmad, 2006. Sumber Daya Manusia Berkualitas mengubah Visi menjadi Realitas. PT. Gramedia Pustaka Utama. Jakarta.

Sekaran, Uma. 20I4, Metodologi Penelitian untuk Bisnis (Research Methods for Business). Buku I Edisi 4. Jakarta: Salemba Empat.

Stoner, Freeman dan Gilbert. 1995, Pengantar Bisnis. Yogyakarta: Graha Ilmu.

Sugiyono. 2008, Statistika Untuk Penelitian. Bandung: Alfabeta.

Sukmadinata, Nana Syaodih. 2003, Landasan Psikologi Proses Pendidikan. Bandung: Remaja Rosdakarya.

Wahjosumidjo. 1991, Kepemimpinan yang Efektif. Yogyakarta: Balai Pustaka.

Wibowo. 2012, Manajemen Kinerja. Jakarta: Rajawali Pers. 